\title{
Are High Risk Patients of Femoral Neck Fractures Predictable from the Severity of Osteoporosis?
}

\author{
Shoji KUMAKI* and Hideki KURIBAYASHI*
}

Proximal femur fractures (PFFs) are a major cause of disability in the elderly. Some reports say that osteoporosis is a factor contributing to PFFs and values of bone mineral density (BMD) can be used to predict PFFs. In this study we investigated the possibility of using BMD monitoring to predict the risk of PFFs.

This study compares a PFF group with a nonfracture control group. The selection criteria for both groups were female patients, age 60 and over, on whom dual energy $\mathrm{x}-$ ray absorptiometry (DXA) was performed. The PFF group was composed of 52 patients who were treated between Feb. 1997 and Nov. 1998 and DXA was performed within two weeks postoperatively. The nonfracture control group was made up of 27 patients who were treated for total knee replacement between April 1998 and Dec. 1998 and DXA was performed within two weeks preoperatively.

Histograms were made using BMD data from lumbar and proximal femor measuring sites. The histograms were used to produce receiver-operating characteristic (ROC) curves. After analysing the histograms and ROC curves, two ranges of interest in each DXA report, neck and Wards were selected as the best sites to use when comparing the PFF and control groups.

The two groups were compared to determine cut-off levels for PFFs. For the assessment of fracture risk of the patients with osteoporosis, we would like to propose for neck, $0.600 \mathrm{~g} / \mathrm{cm}^{2} \mathrm{BMD}$ in which sensitivity is $76 \%$ and specificity is $80 \%$. And for Wards, $0.400 \mathrm{~g} / \mathrm{cm}^{2} \mathrm{BMD}$ in which sensitivity is $71 \%$ and specificity is $81 \%$.

(1) Proximal femoral fracture (2) Osteoporosis (3)Bone mineral density

\section{Introduction}

It is a well-known, and regrettable, fact that elderly patients with hip fractures often end up in a bed-ridden state. It is common knowledge that hip fracture patients suffer

\footnotetext{
* Dept. of Orthopedic Surgery, Hokushin General Hospital of Nagano Prefectural Welfare Federation, 1-5-63 Nishi, Nakano, 383-0012, Japan (受付：2000年 6 月28日)
}

from osteoporosis. Some reports state that the risk of hip fractures can be predicted from the severity of osteoporosis which can be estimated by measuring bone mineral density (BMD). In this study we tried to prove the possibility of the prediction of hip fracture by measuring BMD.

\section{Subjects and methodology}

From February 1997 to November 1998, 
we treated 74 female pafients, aged 60 years and over for osteoporosis-related hip fractures in our department. Of these, we chose 52 cases (52 limbs) as a fracture group and measured BMD within two weeks postoperatively. This group consisted of 20 neck, or medial type, and 32 intertrochanteric, or lateral type, of proximal femoral fractures and their BMD measurements were taken on the nonfracture side, 26 on the right, and 26 on the left. The average age of this group was 79.9 years and the age range was 60-92 years. As a control group, we chose 27 female patients. They were free of hip fractures, but underwent total knee replacement in our department from April 1998 to December 1998. Their BMD measurements were taken within two weeks preoperatively wity their proximal femure sites being measured on the non-operative site, 10 on the right and 17 on the left. The average age was 73.3 years and the age range was $63-84$ years (Table 1 ). The analy- sis by Student- $t$ test showed that there were no significant difference in age between the two groups.

Dual energy $\mathrm{x}$-ray absorptiometry (Expert 2000, lunar company, USA) was used to measure BMDs, which read both lumbar and proximal femur bone densities. In the lumbar spine, the bone density was measured for each lumbar vertebra from the second to the fourth seperately and synthesized for combined area if necessary (Fig. 1). In the proximal femur the bone density was measured by deviding the adjacent area into four parts, which are named neck, Wards, trochanter and shaft in a Expert 2000 BMD report. The value for BMD in Wards is the computer caluculated smallest density figure about the certain square area in the neck, which is not geographically equivalent to the Ward's triangle of the neck (Fig. 2).

In the process of analysis, we selected the three most reliable sites, 2nd-4th Lumbar,

Table 1 Characteristics of the patients in the fracture and nonfracture groups

\begin{tabular}{c|c|c}
\hline & Fracture group & Nonfracture group \\
\hline No. of cases & 52 females & 27 female \\
Age (years : mean, range) & $79.7(60 \sim 92)$ & $73.3(63 \sim 84)$ \\
\hline
\end{tabular}

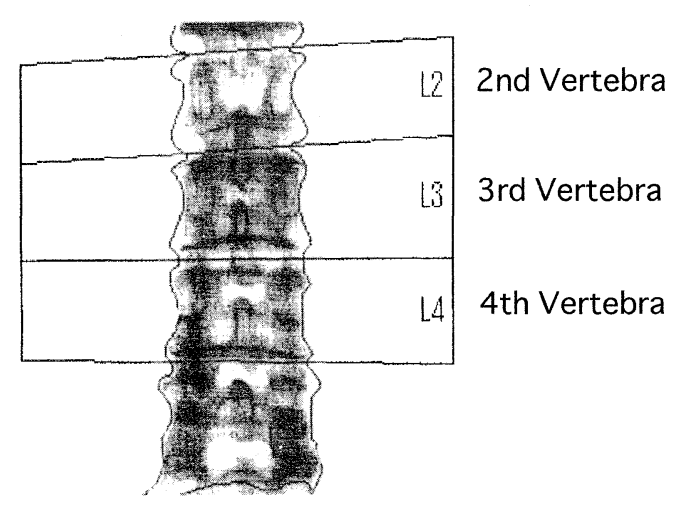

Fig. 1 BMD measurement sites for lumbar spine in DXA

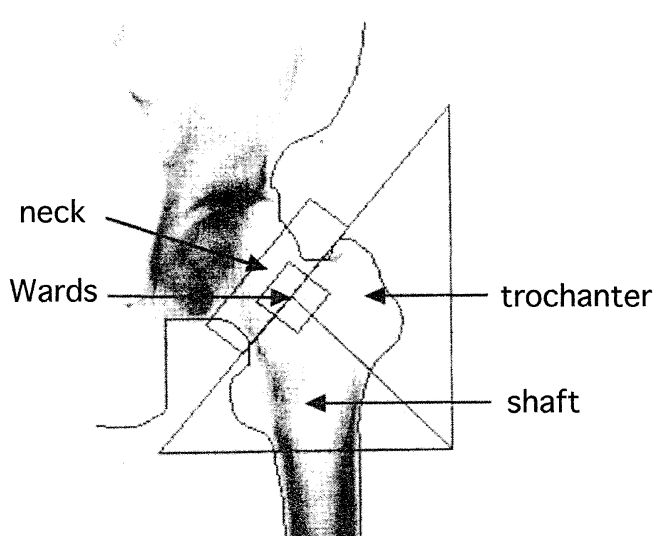

Fig. 2 BMD measurement sites for proximal femur in DXA 
neck, and Wards out of 9 lumbar and proximal femur measuring sites by visually comparing histograms obtained from each. We then determined the cut-off values for femoral fractures from the receiver-operating characteristic, or ROC curves obtained from the above mentioned three sites.

\section{Results}

In the fracture group, the mean densities of the second lumbar vertebra (L2), the third lumbar vertebra (L3), the fourth lumbar vertebra (L4) and from the second to the fourth lumbar vertebrae (L2-4) were $0.716 \mathrm{~g} / \mathrm{cm}^{2}$, $0.766 \mathrm{~g} / \mathrm{cm}^{2}, 0.843 \mathrm{~g} / \mathrm{cm}^{2}$ and $0.775 \mathrm{~g} / \mathrm{cm}^{2}$, respectively. In the nonfracture group, the mean densities of L2, L3, L4 and L2-4 were $0.835 \mathrm{~g} / \mathrm{cm}^{2}, 0.931 \mathrm{~g} / \mathrm{cm}^{2}, 0.988 \mathrm{~g} / \mathrm{cm}^{2}$ and $0.917 \mathrm{~g} / \mathrm{cm}^{2}$, respectively.

In the fracture group, the mean densities of the neck, Wards, trochanter, shaft and total region were $0.535 \mathrm{~g} / \mathrm{cm}^{2}, 0.535 \mathrm{~g} / \mathrm{cm}^{2}, 0.535$ $\mathrm{g} / \mathrm{cm}^{2}, 0.535 \mathrm{~g} / \mathrm{cm}^{2}$ and $0.535 \mathrm{~g} / \mathrm{cm}^{2}$ respectively.

In the nonfracture group, the mean densities of neck, Wards, trochanter, shaft and total region were $0.640 \mathrm{~g} / \mathrm{cm}^{2}, 0.473 \mathrm{~g} / \mathrm{cm}^{2}$, $0.552 \mathrm{~g} / \mathrm{cm}^{2}, 0.866 \mathrm{~g} / \mathrm{cm}^{2}, 0.713 \mathrm{~g} / \mathrm{cm}^{2}$, respectively (Table 2).

In order to evaluate the distribution trait of each site in the fracture group and in the nonfracture group, the data were shown in the form of histograms. Among the four sites in the fracture group, the histogram of L2-4 was most closely distributed in accordance with the normal curve (Fig. 3). In the nonfracture group, of the five proximal femoral measurement sites, only neck and Wards densities were distributed in nearly normal curve (Fig. 4).

Table 2 Bone Mineral Densitise in the Lumbar vertebrae and the Proximal femur

\begin{tabular}{c|c|c}
\hline & $\begin{array}{c}\text { Mean BMD g/cm } \\
\left(\text { range } / \mathrm{cm}^{2}\right)\end{array}$ & $\begin{array}{c}\text { Mean BMD g/cm } \\
\left(\text { range } / \mathrm{cm}^{2}\right)\end{array}$ \\
\hline Lumbar vertebrae & 0.716 & 0.835 \\
L 2 & $(0.354 \sim 1.217)$ & $(0.537 \sim 1.318)$ \\
L 3 & 0.766 & 0.931 \\
L 4 & $(0.353 \sim 1.272)$ & $(0.554 \sim 1.392)$ \\
L 2-4 & 0.843 & 0.988 \\
& $(0.388 \sim 1.373)$ & $(0.644 \sim 1.369)$ \\
neck & 0.775 & 0.917 \\
Wards & $(0.372 \sim 1.251)$ & $(0.614 \sim 1.352)$ \\
trochanter & 0.535 & 0.640 \\
& $(0.292 \sim 0.771)$ & $(0.104 \sim 0.799)$ \\
shaft & 0.349 & 0.473 \\
& $(0.104 \sim 0.600)$ & $(0.231 \sim 0.677)$ \\
total proximal femur & 0.422 & 0.552 \\
& $(0.171 \sim 0.776)$ & $(0.359 \sim 0.702)$ \\
& 0.684 & 0.866 \\
& $(0.392 \sim 1.089)$ & $(0.523 \sim 1.122)$ \\
& 0.561 & 0.713 \\
& $(0.317 \sim 0.888)$ & $(0.447 \sim 0.890)$ \\
\hline
\end{tabular}



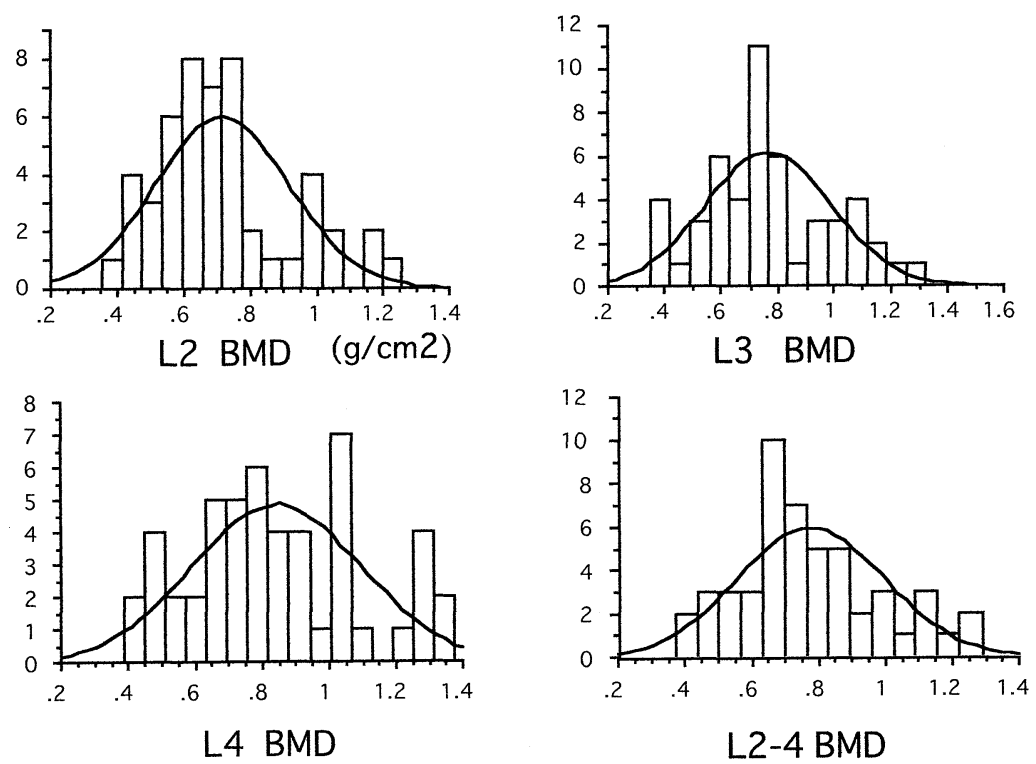

Fig. 3 Histograms of the BMD data for the 2nd lumbar, the 3rd lumbar, the 4 th lumbar and the 2 nd -4 th lumbar vertebrae in the fracture group
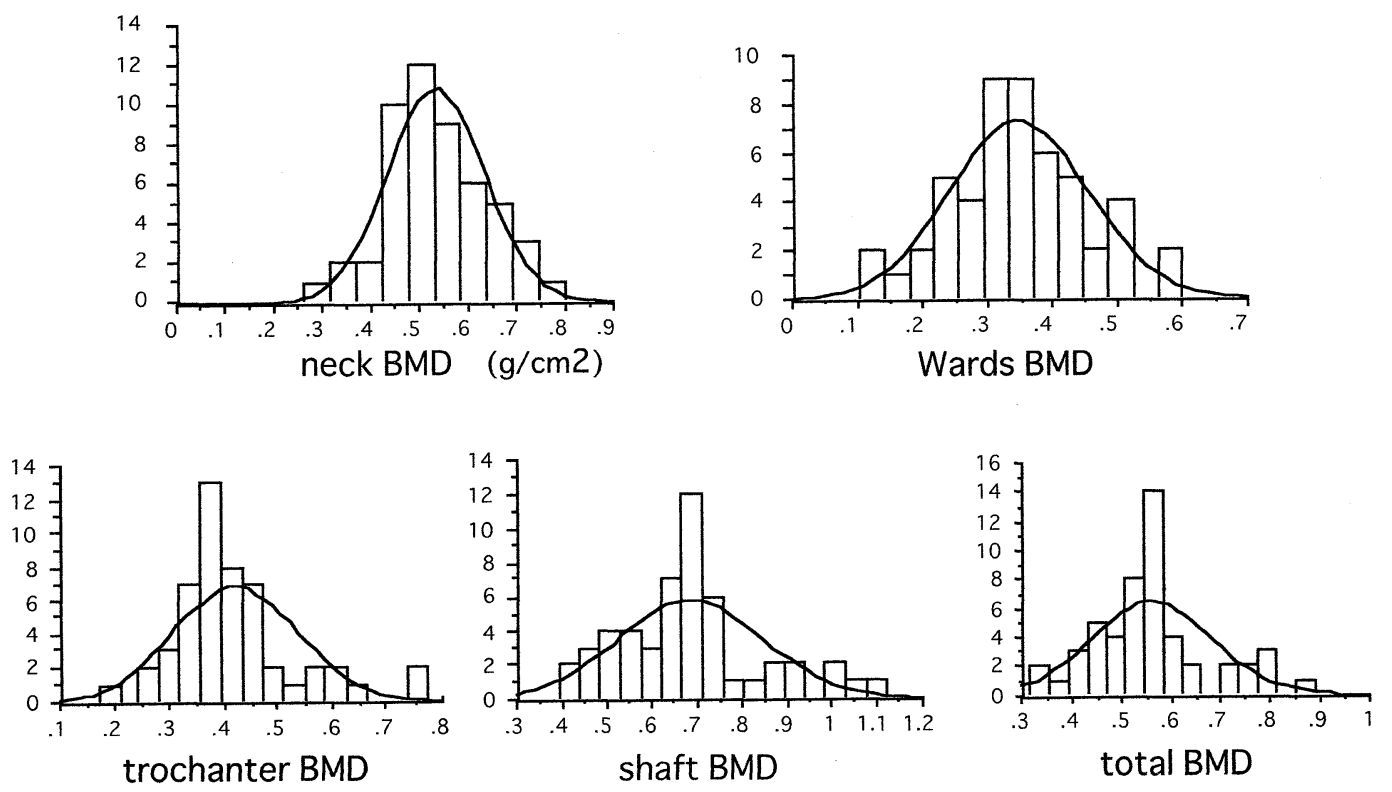

Fig. 4 Histograms of the BMD data for each site of the proximal femur in the fracture group 

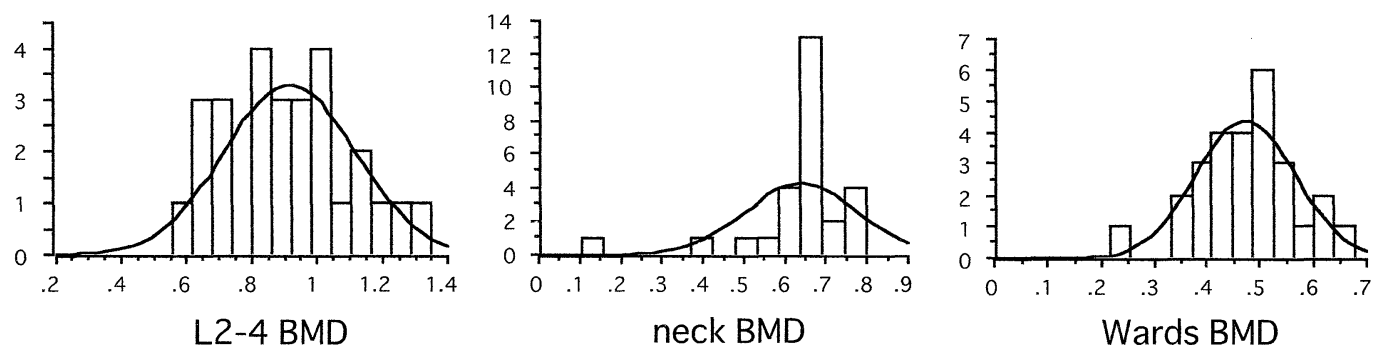

Fig. 5 Histograms of the BMD data for the 2nd-4th lumbar vertebrae, neck and Ward's BMD in the nonfracture group

Therefore, we decided to use data from three sites-L2-4, neck and Wards-for analysis because of their close distribution patterns to the normal curve.

In the nonfracture group, the histogram of Wards density was distributed in a normal curve, however, L2-4 and neck distributions were far from normal curves, probably because of the small number of samples, 27, in this group (Fig. 5).

In order to determine cut-off values for hip fractures, we have first deawn ROC curves of three items-L2-4, neck and Wards. As we expected from the poor normal distribution of L2-4 density in the nonfracture group, the ROC curve of L2-4 did not appear to be acceptable in the graph (Fig. 6). Therefore we tried to set cut-off levels on two items, neck and Wards curves, using the percentile curves of neck and Wards. In the process of assessment of appropriate values for cut-off levels at each site, we determined to put a cut-off level for neck BMD at 0.600 $\mathrm{g} / \mathrm{cm}^{2}$ where the sensitibity is $76 \%$ and specificity $80 \%$, and for Wards BMD at $0.400 \mathrm{~g} / \mathrm{cm}^{2}$ where the sensitivity is $71 \%$ and specificity $81 \%$ (Fig. 7).

\section{Discussion}

It has been suggested that the occurrence of hip fractures is attributable to decreased

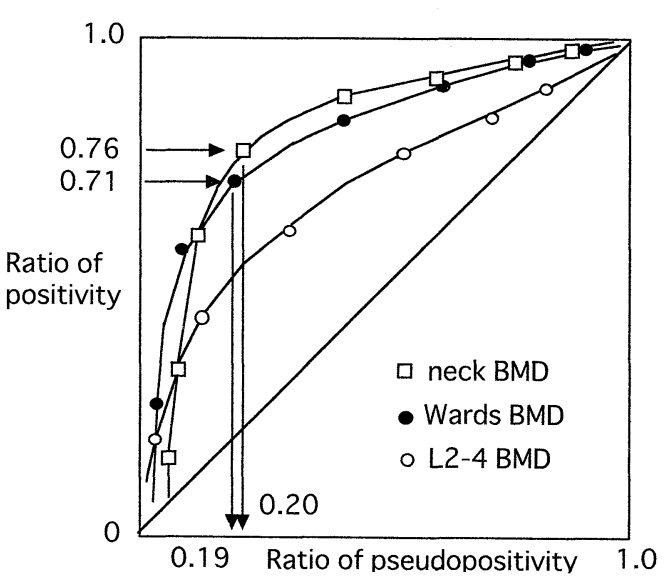

Fig. 6 ROC curves of the BMD in the neck, Ward's and the 2nd-4th lumbar vertebrae derived from the fracture and nonfracture groups

impedance in the skeletal system and increased risk of falling ${ }^{11}$. In daily life, falling seems the most important factor for hip fractures, however, Fujii et al. reported in their study using cadaveric femur bones that the force required to cause fracture in the proximal femur decreased dramatically as the region became more osteoporotic, citing that the grade II or III osteoporotic states in Singh index ${ }^{2)}$ were 3 or 4 times more susceptable to fracture than the state of Grade $\mathrm{IV}^{3)}$. This leads us to think that the measurement of $\mathrm{BMD}$ is essential for precise assessment of the risk of fracture in the osteoporotic age 

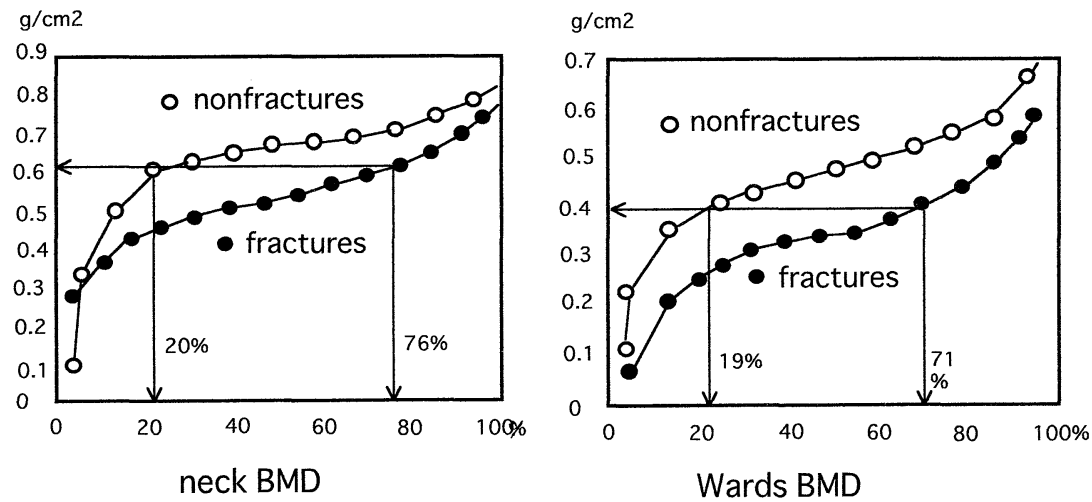

Fig. 7 Percentile graphs of the BMD of the fracture and nonfracture groups for the neck and Ward's at the proximal femur to figure out sensitivity and specificity for neck fracture risk

group.

In our daily medical practice, the lumbar spine is the main target for measurement of bone mineral density because of its accuracy in measurement by dual energy $x$-ray absorptiometry. Since the lumbar spine consists in most part of cancellous bone, it can more easily reflect bone loss in the menopausal phase. But measurement of spine density in elderly population is not always accurate because of spondylosis of the lumbar vertebrae or occurrence of calcification of the abdominal aorta $^{4}$. On the other hand, scanning on the proximal femur can avoid such inaccuracies in measurement, because of no or less severe change with aging.

Cummings et al. concluded that from measurements of bone density in the proximal femur predict fractures can be predicted better than from measurements taken at the other skeletal sites ${ }^{5}$. Our results confirm theirs. Among the several sites in the proximal femur, we concluded that monitoring of BMD in either neck or Wards is the best site to refer to in order to predict hip fractures.

The cut-off levels that we determined in this study, on the basis of percentile graphs and ROC curves by setting sensitivity in the seventies and specificity in the eighties, which we think the reasonable values for clinical analysis, are $0.600 \mathrm{~g} / \mathrm{cm}^{2}$ for neck and $0.400 \mathrm{~g} / \mathrm{cm}^{2}$ for Wards. These cut-off levels coincide well with the value at the 90th percentile for hip fractures in other reports published in Japan.

As the number of elderly people increases in Japan, the number of osteoporotic patients goes up as well. As a result, more people suffer from osteoporosis-related fractures such as spine, forearm, shoulder or hip fractures. Hip fracture is of course the most crucial one for the elderly because of restriction on their daily activities and social life, the high cost of treatment including surgical operation, and occasional fatalities. It is important to assess major risk factors for hip fractures for clinical practice.

We would like to propose the above mentioned cut-off levels neck and Wards bone densities in a DXA study as the reference values for assessing the risk for fractures in patients who have osteoporosis. For patients whose bone densities are below the cut-off levels, we will be able to warn them of the 
presence of the high risk of hip fractures beforeband, giving them suggestions about prevention from falling or providing indoor conditions free from falling.

\section{References}

1) Melton L J, et al. Osteoporosis and the risk of hip fracture. Am J Epidemiol 1986 ; 124 : 254-261.

2 ) Singh M, et al. Changes in trabecular pattern of the upper end of the femur as an index of osteopo- rosis. J Bone Joint Surg 1970 ; 52-A : 457-467.

3) Fujii M. Experimental study on the mechanism of femoral neck fractures. J Jpn Orthop Assoc 1987 ; $61: 531-541$.

4) Mazess RB, et al. Radial and spinal bone mineral density in a patient population. Arthr Rheum $1988 ; 31: 891-897$.

5 ) Cummings, et al. Bone density at various sites for prediction of hip fractures. Lancet $1993 ; 341: 72$ -75 .

\section{大腿骨頸部骨折における骨粗鬆症の関与について 骨折危険群は予測できるか?}

\section{熊木昇二*，栗林秀樹*}

[目的］大腿骨頸部骨折（以下頸部骨折）は老人の寝たきりの原因となりやすい。頸部骨 折には骨粗鬆症が関与していると言われており，骨折のリスクを予測するのに骨密度（以 下 BMD）測定の意義が報告されている。今回われわれは大腿骨頸部骨折の危険群を BMD で予測可能か明らかにすることを目的とした。

[対象と方法］97年 2 月から98年11月までに当院で手術をした60歳以上の女性の大腿骨頸 部骨折は74例77肢で，このうち DXA 法を施行した52例52肢を骨折群とした。非骨折群と して 98 年 4 月から 98 年12月までに人工膝関節置換術を施行し術前にDXA 法を施行した頸 部骨折の既往のない女性 27 例を選んだ。各腰椎 $\mathrm{BMD}$, 大腿骨近位部 BMD の度数分布表 を両群で作製し，検討に值する BMD を選定した。それらの BMD の ROC 曲線を作製し 正確な指標となる BMD の決定と cut off 值の決定を行った。

[結果と結論] 度数分布表は L2-4 BMD, neck BMD, wards BMD において正規分布を なした。これらの ROC 曲線を作製すると neck BMD, wards BMDがより正確な指標と いえ, neck BMD の cut off 值は $0.600 \mathrm{~g} / \mathrm{cm}^{2}$ (感度 $76 \%$, 特異度 $80 \%$ ), wards BMDのそ れは $0.400 \mathrm{~g} / \mathrm{cm}^{2}$ (感度 $71 \%$ ，特異度 $81 \%$ ）とすることが可能であった

\footnotetext{
${ }^{*}$ 長野県厚生連北信総合病院整形外科
} 